\title{
Graficzne przyswajanie zapożyczeń z języka angielskiego w języku rosyjskim początku XXI wieku i moda językowa
}

Słowa klucze: zapożyczenie, przyswajanie graficzne, cyrylica, alfabet łaciński, wtręt

Jak wiadomo, w procesie wchodzenia do danego języka zapożyczane słowo przechodzi kilka etapów przyswajania: fonetyczny, morfologiczny, semantyczny. Niektórzy autorzy zwracają uwagę na normatywny aspekt ortograficznego przyswajania zapożyczeń (Нечаева 2008). Мy zajmiemy się tu procesem, który nazwiemy graficznym przyswajaniem zapożyczeń.

Język rosyjski zapożycza większość wyrazów obcojęzycznych z języków europejskich, które posługują się innym alfabetem, czyli mają inną, w porównaniu z językiem rosyjskim, grafię. W dzisiejszych czasach przeciętny Rosjanin, który ukończył szkołę średnią, jest w stanie czytać litery alfabetu łacińskiego. W związku z tym pojawia się problem graficznego przyswajania zapożyczeń; innymi słowy, wyraz może wejść do języka, a ściślej do jego formy pisanej, i funkcjonować początkowo nie w transliteracji, jak to było 10-20 lat temu, kiedy język angielski nie był jeszcze tak szeroko rozpowszechniony, ale w pisowni oryginalnej. W ten sposób w tekstach rosyjskich pisanych cyrylicą coraz częściej pojawiają się wyrazy pisane alfabetem łaciń- 
skim, np.: Bluetooth обеспечивает обмен информацией между такими устройствами как карманные и обычные персональные компьютеры (Wikipedia), a nawet wyrazy o pisowni mieszanej - słowa-«centaury» (termin L. P. Krysina, por. Крысин 2008): web-мастер, vip-nерсона, itp. Szczegółowa historia «intrygi łacińsko-cyrylickiej» przedstawiona jest w artykule T. M. Grigoriewy, poświęconym rywalizacji pomiędzy tymi dwoma systemami zapisu, począwszy od XVII wieku po dzień dzisiejszy. Autorka dochodzi do wniosku, że ,proces wprowadzania alfabetu łacińskiego do tekstów rosyjskich w okresie poradzieckim okazuje się czymś nowym tylko w porównaniu z okresem radzieckim" z jego ścisłą orientacją na cyrylicę (Григорьева 2009: 9). W naszym artykule zwrócimy uwagę nie na przykłady wpływu na grafikę rosyjską „,z góry”", tylko na przypadki „naturalnego”, niesprowokowanego sztucznymi reformami, wchodzenia wtrętów łacińskich do tekstu cyrylicznego.

Ukształtowany w okresie poradzieckim stosunek do takiego stanu rzeczy w nowoczesnej ortografii jest w środowisku uczonych różny. L. P. Krysin na przykład, uznając istnienie podobnych środków leksykalnych, uważa, że nie należą one do języka rosyjskiego, lecz są jedynie obcojęzycznymi wtrętami w języku (Крысин 2008: 173). G. N. Skliariewskaja - wprost przeciwnie - nadaje takim wyrazom prawo obywatelstwa, a nawet poświęca im w swoim słowniku osobny rozdział (Скляревская 2006: 1111-1132). Ogólnie, jak zauważa D. E. Rozental, kwestia przekazu słów, które zachowują swoją postać obcojęzyczną i które są odbierane jako wtręty z innych języków, „pozostaje niewystarczająco opracowana przez ortografię rosyjską" (Розенталь и др. 1999: 78). Jeden z najbardziej autorytatywnych poradników dotyczących norm języka rosyjskiego radzi unikać pisowni mieszanej, „gdyż utrudnia to percepcję tekstu" (Розенталь и др. 1999: 79).

A. I. Diakow wyjaśnia atrakcyjność podobnych elementów procesem przyłączania się Rosji do wspólnoty międzynarodowej (Дьяков 1999: 113-120). E. O. Filinkowa uważa, że sytuacja w ortografii rosyjskiej stanowi ,odzwier-

1 Por. liczne propozycje przejścia ortografii rosyjskiej z cyrylicy na łacinę, np. propozycja K. M. Kodzińskiego (Кодинский 1842), mająca na celu uproszczenie ortografii rosyjskiej, dyskusje o przejściu na łacinę w drugiej połowie wieku XIX (Komisja ortograficzna pod kierownictwem W. J. Stojunina), wypowiedzi J. K. Grota (Грот 1873), dyskusje na temat przejścia na łacinę w czasach reformy ortografii w roku 1917 i w latach 30. XX wieku w Związku Radzieckim (Русская латиница). 
ciedlenie umocnienia się «swobody ortograficznej» jako przeciwwagi dla «ortograficznego reżimu», co z kolei odzwierciedla zmiany w społecznym i gospodarczym życiu kraju" (Филинкова 2001: 166-172). Oprócz obiektywnej konieczności posługiwania się wyrazami obcojęzycznymi, kiedy w języku-receptorze brak jest odpowiedniego słowa na określenie danego pojęcia lub przedmiotu (bluetooth), lub też gdy dawne określenie jest nieco niezgrabne, a język dąży do zwięzłości (web - всемирная мировая паутина 'ogólnoświatowa sieć / pajęczyna'), słowa-«centaury» (barbaryzmy) pojawiają się pod wpływem przyczyn społeczno-psychologicznych: słowo w języku obcym jest uważane za bardziej szykowne, za lepsze; można tu mówić o wytworzeniu się mody językowej na wyrazy pisane alfabetem łacińskim.

A. Mustajoki i I. W. Wiepriewa (Мустайоки, Вепрева 2006: 45-63), opierając się na koncepcji A. B. Hofmana (Гофман 1994), rozpatrują w swoim artykule słowo jako obiekt modny i wyszczególniają następujące cechy wyrazu modnego (charakterystyczne, zdaniem A. B. Hofmana, dla dowolnego modnego obiektu): nowoczesność (słowo powinno odpowiadać swoim czasom, być wyrazem chwili bieżqcej), masowość (częstotliwość użycia danego słowa), demonstratywność (słowo powinno posiadać wyrazistą formę zewnętrzną; według obserwacji badaczy, ,jednym ze źródeł atrakcyjności jest egzotyczność formy obcojęzycznego słowa. To, co jest kulturowo oddalone, «obce», ma w przypadku modnego obiektu zawsze zabarwienie pozytywne", Мустайоки, Вепрева 2006: 54), ludyczna natura modnego słowa (modne słowo nie nazywa nowego zjawiska, ono nazywa po nowemu zjawiska już istniejące; tak więc mamy w języku mnóstwo dawnych wyrazów i ich obcojęzycznych zamienników).

W naszym artykule będziemy rozpatrywać jako obiekt modny nie pojedyncze słowa, jak to czynią w swojej pracy A. Mustajoki i I. W. Wiepriewa, lecz całe zjawisko mieszania dwóch systemów graficznych w języku rosyjskim przełomu wieków XX i XXI.

Po raz pierwszy wyrazy pisane alfabetem łacińskim w tekście pisanym cyrylicą pojawiły się w okresie pieriestrojki, według danych Narodowego Korpusu Języka Rosyjskiego - mniej więcej w roku 1986; por.: Не сорваться бы, не начать бы спрашивать об очевидном - тогда заподозрят. И не перестараться, играя «VIP». Пока - сходит с рук. (Андрей Лазарчук, Там вдали, за рекой...). Współcześnie na zapytanie VIP wyszukiwarka Google (http://www.google.ru/) wyświetla ok. 11900000 rezultatów. Tak samo im- 
ponujące rezultaty wyszukiwarka pokazuje dla innych słów, które, według naszych obserwacji, stanowią częste wtręty w tekstach pisanych cyrylica i które weszły do Dodatku do Opisowego słownika języka rosyjskiego poczatku XXI wieku G. N. Skliariewskiej (Скляревская 2006). Podajmy kilka przykładów: $C D-13800000$ rezultatów; IT - 92800000 rezultatów (zarówno jako pojedyncze słowo, jak i jako część słów-«centaurów»: IT-собеседование 'rozmowa o pracę w branży IT / informatycznej', IT-специиалист 'specjalista informatyk', itp.); sale 'wyprzedaż' - 2490000 rezultatów, itd. ${ }^{2}$ Opierając się na tych danych statystycznych, można stwierdzić, że częstotliwość występowania wyrazów pisanych alfabetem łacińskim w tekstach pisanych cyrylicą jest wysoka i zjawisko to daje się opisać taką cechą modnego obiektu, jak masowość.

Jeśli przyjrzymy się Dodatkowi do słownika G. N. Skliariewskiej, gdzie zebrane są nieprzyswojone graficznie zapożyczenia, zobaczymy, że wszystkie te słowa nazywają zjawiska współczesne związane z komputeryzacją (CD, IT, flash), show-businessem i reklamą ( $P R$ i jego derywaty, słowa-«centaury», acid jazz, DJ), modą (couture, prêt-à-porter), ekonomiką (blue chip, promotion), to znaczy związane z najbardziej aktualnymi sferami życia człowieka współczesnego, co pozwala uznać je za nowoczesne, związane z teraźniejszością.

Cechę demonstratywności, właściwą dowolnemu obiektowi modnemu, można zilustrować najbardziej wyraziście na przykładzie wtrętów pisanych alfabetem łacińskim. Wyrazy pisane literami łacińskimi, słowa-«centaury» są w największym stopniu egzotyczne i wyróżniają się z ogólnego dyskursu bardziej niż barbaryzmy zapisane cyrylica (por. коучер, тендер, itp.). L. W. Knorina (Кнорина 1996) na określenie podobnego zjawiska wprowadza do obiegu naukowego termin cecha hieroglificzności, którą, jej zdaniem, mają elementy języka niezrozumiałe dla większości użytkowników. Oczywiście, to właśnie ta cecha pozwala elementom języka spełniać funkcję przyciągania uwagi: wszystko to, co nie do końca zrozumiałe, rzuca się w oczy. Pojawiają się w związku z tym nazwy firm i produktów, które są pisane alfabetem łacińskim: Smirnoff, Nemiroff (nazwy wódek), Lada (nazwa marki rosyjskiego samochodu). Przytoczone przykłady można wyjaśnić jeszcze dążeniem producenta do wprowadzenia swego towaru na rynek międzynarodowy,

2 Liczby dotyczą zapytania wyszukującego strony tylko w języku rosyjskim. 
ale już nazywania po angielsku lub w pisowni mieszanej przedsiębiorstwa, o którym z góry wia do mo, że nie wejdzie na rynek międzynarodowy, nie da się wyjaśnić inaczej, niż tylko wpływem mody (por. np. nazwy niektórych firm w Ufie: pracownie krawieckie Rossita, Michael, Taste Allure; agencja detektywistyczna Sh. Холмс; studio projektów graficznych Art-проекm). Modne stało się wykorzystywanie wtrętów pisanych alfabetem łacińskim w ogłoszeniach reklamowych i sloganach, gdzie pełnią one funkcję przyciagania uwagi (dokładniej na ten temat - patrz. Копрева 2006).

Jak zauważają A. Mustajoki i I. W. Wiepriewa, słowa nazywające nowe realia raczej nie mogą stać się modne z powodu braku w ich wypadku pierwiastka zabawowego, polegającego na tym, że wyraz modny zastępuje jakiś inny, który istniał już wcześniej; użytkownik języka wybiera dobrowolnie słowo modne, a nie jakieś inne (gdy słowa oznaczają nowe realia, użytkownik języka nie ma wyboru, gdyż - z reguły - istnieje tylko jedna nazwa). Może się wydawać, że skoro takie określenia, jak bluetooth, hi-fi, mail, itp. nazywają nowe realia, których przedtem nie było, to teoretycznie nie moga one stać się wyrazami modnymi. Reprezentujemy pogląd, że to nie słowa są modne, lecz sam fakt zapisania ich literami alfabetu łacińskiego. Element zabawy językowej zawiera się w tym, że w większości wypadków użytkownik języka ma wybór: może napisać słowo albo alfabetem łacińskim, tak jak w przytoczonych przykładach, albo cyrylicą (блютус, хай-фай, мейл); dla większości rozpatrywanych wyrazów istnieje już wariant pisany cyrylicą, co oznacza, że proces przyswojenia graficznego został zakończony. Porównajmy statystyki: na zapytanie mail Google.ru podaje 436000000 rezultatów, a na zapytanie мейл - tylko 1350 000, i to pomimo tego, że słowo to przeszło proces przyswojenia graficznego już dawno (według NKJR, wyraz ten pisany cyrylicą funkcjonował już w roku 2005).

Najbardziej wyraziście demonstratywność i pierwiastek zabawowy, charakteryzujące rozpatrywane zjawisko jako element mody językowej, występują w tytułach utworów literackich i w pseudonimach. O ile nam wiadomo, zjawisko to nie stało się jeszcze przedmiotem szczegółowej analizy, dlatego też zatrzymamy się nad nim i omówimy je bardziej szczegółowo.

A. I. Diakow zauważył, że zjawisko wtrętów obcojęzycznych w tytułach dzieł literatury pięknej raczej rzadko jest „obliczone na wysoki stopień kompetencji językowych odbiorców" (Дьяков 2003: 36). Jednakże w roku 2009 możemy mówić o wysokim stopniu rozprzestrzenienia się tego 
zjawiska. Wtręty pisane alfabetem łacińskim spotykamy nie tylko w tytułach recenzji i utworów ambitnych, ale także w dziełach literatury bulwarowej, literatury (według określenia samych autorów) typu glamour, a nawet w pseudonimach autorów. Wystarczy wejść do dowolnej księgarni w Rosji, żeby zobaczyć na półkach dziesiątki podobnych przykładów w tytułach książek, por. В. Пелевин, Етріге V; М. Елизаров, Pasternak; Ева Пунш, Kpыcolove; С. Минаев, Духless; О. Робски, Про любоfflon oraz Casual; Ж. Срибная, Staff only, или Посторонним B.; i w pseudonimach autorów, por. Александр Таvговский, Талаssa. Natomiast w książce P. Dunajewa i A. Potapowa pod tytułem Маунтинборд: доска-внедорожник (2008), pomimo licznych zapożyczeń (które służą do nazwania nowych realiów), nie ma ani jednego wyrazu napisanego alfabetem łacińskim, por. poniższy cytat pełen barbaryzmów: „Маунтинбординг - именно то, что нужно жадному до адреналина р а й де ру. Он пришелся по душе сноубордистам как способ избежать межсезонья, оставаясь верными доске. Переориентировались и кай т серферы -пристегнув к ногам б о р д -внедорожник, развернули к а й т ы в сторону песчаных пляжей и травянистых долин” (П. Фунаев, А. Потапов, 2008, s. 3). Książka adresowana jest do wąskiego kręgu czytelników, interesujących się sportami ekstremalnymi, a zatem nie ma potrzeby reklamować jej szerzej za pomocą modnych wyrazów i grafiki łacińskiej.

Zabawa $\mathrm{z}$ grafiką łacińską $\mathrm{w}$ tytule utworu znakomicie poddaje się analizie na przykład u Wiktora Pielewina. Powieść pt. Empire $V$ to dowcipna satyra na współczesną rzeczywistość, w której ludzie potrzebni są jedynie po to, aby zdobywać pieniądze i produkować pewną substancję, którą żywią się wampiry. Według równie dowcipnej recenzji tej powieści, Empire $V$ to utwór otwierający czytelnikowi oczy „,na podstawową podłość człowieka, na fałsz światowej kultury (typu glamour-discourse), idiotyzm narodu rosyjskiego i bestialstwo dzisiejszego życia" (Немзер 2006). Dlatego też modne ujęcie tytułu powieści w alfabecie łacińskim w duchu glamour-discourse jest w pełni wytłumaczalne i wpisuje się w ogólny satyryczno-filozoficzny kontekst powieści: są tu i aluzje do stylu empire w architekturze i sztuce początku XIX wieku (w niektórych recenzjach tytuł powieści jest napisany cyrylicą: Ампир B, por. francuskie empire - nazwa stylu w sztuce), i zabawa $\mathrm{z}$ fonetyczną postacią wyrazu вамnup 'wampir' (pierwsza litera przestawiona na koniec), prócz tego, słowo empire w języku angielskim znaczy 'im- 
perium', a w powieści jest mowa o świecie wampirów, który metaforycznie można określić tym słowem.

W powieści Michaiła Elizarowa Pasternak ${ }^{3}$ (М. Елизаров, Pasternak, Москва, 2003, Ad Marginem) mowa jest o złośliwym demonie, który niszczy pradawne podstawy rosyjskiej duchowości. Opowieść rozgrywa się na dwóch poziomach: fizycznym, do którego można odnieść sceny bitew, i lingwistycznym, obejmującym filozoficzne dyskusje i zabawy językowe. Ażeby przeciwstawić świat rosyjski obcemu złu, na poziomie lingwistycznym autor ucieka się nie tylko do gry słów (Пастернак, Пастер Нак, Пастер Ham), lecz także do zabawy z zapisem. Imię wroga wszystkiego, co rosyjskie, zapisano alfabetem łacińskim.

Ewa Punsz (Ева Пунш, Крысolove, Москва, 2009, АСТ) pisze w swojej powieści miłosnej o dziewczynie, która panicznie bała się szczurów, lubiła na nie polować z wiatrówki, z psem specjalnej rasy, i często zmieniała kochanków. Każdy rozdział powieści poprzedzony jest epigramem. Wśród nich znalazło się miejsce dla fragmentów z poematu Крысолов (Szczurołap) Mariny Cwietajewej i z opowiadania Aleksandra Grina pod tym samym tytułem. Już sam tytuł Kpblcolove wywołuje liczne skojarzenia kulturowe, począwszy od legendy o szczurołapie, a kończąc na utworach współczesnych. Acя-lina, główna bohaterka powieści, przyciąga mężczyzn niczym szczurołap i tak samo ich niszczy. Element love w tytule podpowiada gatunek książki - jest to powieść miłosna; ponadto stanowi pseudodowcipną zabawę językową, której przykładów jest w tej powieści sporo, i - naszym zdaniem - nie pełni żadnych innych funkcji estetycznych.

Nie wiadomo, dlaczego pisarz Александр Тавровский (Aleksandr Tawrowskij), pretendujący do miana autora, którego utwory reprezentują literaturę poważną, po ukazaniu się bardzo dobrze przyjętej powieści Kanibal z Rotenburga, postanowił zmienić nazwisko na Таvroвский. Jak wyjaśnić wtręty alfabetu łacińskiego do (i bez tego oryginalnego) pseudonimu pisarki, autorki literatury kobiecej Taлassbl? Należy tu wspomnieć, że w wyszukiwarkach internetowych (Google, Yandex) hasło Tалаssa lub Таvговский zostaje skorygowane; system proponuje rozpoczęcie poszukiwania słowa zapisanego wyłącznie cyrylicą. Informacje o autorach, a także omówienia i reklamy ich książek napisane są wyłącznie cyrylicą, w przeciwnym razie

${ }^{3} \mathrm{~W}$ tytule powieści nazwisko rosyjskiego pisarza noblisty jest zapisane łacińskimi literami. 
system po prostu nie pokaże odpowiednich witryn (por. np. stronę wydawnictwa Гелиос (Helios), które wydaje książki Talassy: https://www.labirintshop.ru/books/151453/ lub rezultaty zapytania Таvговский w wyszukiwarce Yandex: http://yandex.ru/yandsearch?text=Tavroвский, z których wynika, że poszukiwana fraza nie została znaleziona).

Modne prądy dotyczą nie tylko literatury pięknej, ale także poradników $\mathrm{z}$ gatunku how to do (kolejny wtręt!). Książki z tego gatunku stały się bardzo popularne najpierw w USA, a potem w Rosji; obecnie w każdej księgarni znajduje się specjalny dział wydań tego typu. Ażeby skłonić klienta do zakupu książki konkretnego wydawnictwa, stosuje się różne chwyty reklamowe, do których należy także zabawa z zapisem. Jako przykład możemy tu wymienić książkę kucharską pod tytułem Кулинарное M EN U на 365 дней. Более 1000 рецептов на любой вкус (wyd. Эксмо, Moskwa 2008).

W większości wypadków podobne „słowotwórstwo” służy swoistej reklamie; ma na celu przyciągnięcie uwagi do danego autora lub do określonej książki.

Podobna sytuacja istniała już w ortografii rosyjskiej, na przykład w wieku XIX. W warunkach dwujęzyczności francusko-rosyjskiej klasyczne teksty literackie pisarzy rosyjskich oraz teksty niebeletrystyczne (korespondencja, dziennikarstwo) są pełne wtrętów zapisanych za pomocą alfabetu łacińskiego. Nie mówimy tu o takich wypadkach, jak pierwszy rozdział pierwszej części Wojny i pokoju Lwa Tołstoja, prawie w całości zapisany po francusku oraz list Julie Karaginy do Marii w rozdziale dwudziestym pierwszym pierwszej części książki (też zapisany po francusku). Chodzi nam o takie wypadki, kiedy autor nie potrafił albo nie chciał użyć danego słowa w języku rosyjskim, używając barbaryzmu (w pisowni łacińskiej): - Что вы хотите, чтоб я делал! - сказал он наконец. - Вы знаете, я сделал для их воспитания все, что может отец, и оба вышли des imbéciles. (Л. Н. Толстой, Война и мир, Москва 1973, Художественная литература, t. 4, s. 11). W niektórych wypadkach piszący nawet uzasadnia swój wybór, wyjaśniając, że nie wie, jak przetłumaczyć dane słowo:

\section{Она казалась верный снимок}

Du comme il faut... (Шииков, прости:

Не знаю, как перевести.)

(A. Puszkin, Eugeniusz Oniegin, VIII rozdział, XIV), 
lub że odpowiedniego słowa w języku rosyjskim nie ma: На русском языке нет слова, которое имеет смысл при оценке людей; это франиузское слово: comme il faut. (W. Meszczerski, Moje wspomnienia, 1897). Ciekawym przykładem wydaje się fragment z Iwana Turgieniewa, gdzie jedno i to samo słowo barbaryzm w różnych formach gramatycznych pisane jest to cyrylicą, to pisownią łacińską: Mes s i eurs, позвольте вас познакомить: это м с вё Вольдемар, сын нашего соседа. (И. С. Тургенев, Первая любовь, Москва-Ленинград 1965, Наука, t. 9, s. 24).

Jednak między sytuacjami językowymi XIX wieku oraz przełomu wieków XX i XXI istnieje pewna różnica. W wieku XIX wykształceni Rosjanie porozumiewali się swobodnie po rosyjsku i po francusku, co można wywnioskować z utworów rosyjskiej literatury klasycznej; podane przykłady - naszym zdaniem - są ilustracją zjawiska dwujęzyczności. W Rosji współczesnej językiem komunikacji jest rosyjski; język angielski, z którego zapożyczona jest większość słów, nie jest językiem interakcji społecznej. Według naszych obserwacji oraz obserwacji kolegów wykładowców języka angielskiego na wydziałach niehumanistycznych, bardzo nieliczna grupa studentów i absolwentów wyższych uczelni potrafi dziś swobodnie komunikować się w języku angielskim; zdecydowana większość potrafi jedynie pisać i czytać ze słownikiem. Mało prawdopodobne więc jest to, że analizowany problem ortografii rosyjskiej jest odbiciem fenomenu dwujęzyczności.

Tak więc w języku rosyjskim przełomu XX i XXI wieku możemy zaobserwować ciekawe zjawisko: zgodnie z aktualnymi obserwacjami uczonych, dotyczącymi zachowania się zapożyczanych wyrazów w języku receptorze, język powinien «przerobić» zapożyczone słowa, dostosować je do reguł swojego funkcjonowania, czyli przyswoić. Jeśli mówimy o graficznej postaci wyrazu, to, podążając za tą logiką, język powinien był stopniowo zastępować wyrazy pisane alfabetem łacińskim ich wariantami pisanymi cyrylica (вип powinien zastąpić słowo VIP, блютус powinien zastąpić słowo bluetooth itp.); por. np. pracę E. S. Juchminy, w której autorka umieszcza nawet tabelkę odpowiedników do przekodowywania angielskich liter i zbitek literowych na cyrylicę przy graficznym przyswajaniu terminologii komputerowej (Юхмина 2009: 85-89). Należy tu zauważyć, że według danych Narodowego Korpusu Języka Rosyjskiego, na początku wieku XX liczba wtrętów obcojęzycznych w tekstach cyrylicznych znacznie się zmniejszyła - pozostały one w większości wypadków jedynie tam, gdzie autor stosuje mowę bezpo- 
średnią w języku francuskim: "A la guerre comme a la guerre», - зачемто перевел он по-франиузски. (Boris Sawinkow, pseud. Wiktor Ropszyn, To, czego nie było, 1912). Czasem grafika łacińska bywa też używana do zapisu nazw własnych: Toт же автор приводит из «New York Herald'a»... (И. И. Мечников, Этюды оптимизма, 1907-1913); Из работ Lumтеr'a известны количества световой энергии (яркости), которые приходятся на полосу 800-700 для разных температур. (P. N. Lebediew, Listy, 1905). Po rewolucji wtręty oparte na grafice łacińskiej praktycznie zniknęły z języka. Głównym powodem ich zniknięcia było to, że inteligencja musiała emigrować, a robotnicy i chłopi albo nie rozumieli francuskich słów typu ком иль фо, мадам (comme il faut, madame), albo używali ich z odcieniem pejoratywnym. $\mathrm{Z}$ upływem czasu nawet imiona własne zaczęto pisać w transliteracji cyrylicznej.

Dzisiaj obce graficznie warianty nie tylko nadal współistnieją z cyrylicą, lecz na dodatek cieszą się większą popularnością wśród użytkowników języka. Wtręty pisane alfabetem łacińskim nie tylko nie znikają, ale wręcz mnożą się, pojawiając się zarówno w wyrazach dawnych, jak i w słowach utworzonych w języku rosyjskim na bazie rdzeni obcojęzycznych, co przejawia się w literaturze i w reklamie jako zabawa językowa (Про любоff, Kpысcolove, IT-технология, SMS-ка і SMSка). Czas pokaże, czy to zjawisko okaże się, jak mówi M. Epsztejn (Эпштейн 2000), ,zupełnym więdnięciem języka rosyjskiego", czy tylko przemijającą zabawą językową, którą wykorzystują literaci i biznesmeni i która staje się częścią współczesnej kultury masowej.

\section{Bibliografia}

Гофман А. Б., 1994, Мода и люди. Новая теория моды и модного поведения, Москва: Наука.

ГригорьевА Т. М., 2009, Латиница против кириллииы и vice versa // Интернетконференция «КИРИЛЛИЦА - ЛАТИНИЦА - ГРАЖДАНИЦА» [online], http://www.mion.novsu.ac.ru/gev/projects/cur/Grigorieva_lat.pdf.), [28.10.2009].

Грот Я., 1873, Из статьи «Орфографическая распря», w: Я. Гротъ, Спорные вопросы русскаго правописанія отъ Петра Великаго доныниь [online]: http://imwerden.de/pdf/grot_spornye_voprosy_russkago_pravopisanija_1873. pdf [8.10.2010]. 
Дьяков А. И., 1999, Англоязычные варваризмы в языке города, Лингвистический ежегодник Сибири 1, Красноярск, s. 113-120.

Дьяков А. И., 2003, Причины интенсивного заимствования англицизмов в современном русском языке, w: Язык и культура. Сборник статей Всероссийской научной филологической конференции, Новосибирск: Новосибирское книжное издательство, s. 35-43.

Кнорина Л. В., 1996, Свойство иероглифичности и его влияние на употребление слова, [online], http://lidiaknorina.narod.ru/svojstvo.htm, [10.01.2010].

Кодинский К. М., 1842, Uproscenie ruscoi grammatichi, Санкт-Петербург.

КопревА Л. Г., 2006, Иноязычные вкрапления в региональной пресс-рекламе, Политематический сетевой электронный научный журнал Кубанского государственного аграрного университета 22, s. 314-321, [online], http:// ej.kubagro.ru/2006/06/pdf/25.pdf, [28.10.2009].

Крысин Л. П., 2008, Активные процессы в русском языке конца XX - начала XXI века, w: Л. П. Крысин (red.), Современный русский язык. Активныле процессы на рубеже XX-XXI веков, Москва: Языки славянских культур, s. 13-32.

МуСТАЙоки А., ВЕПРевА И. В., 2006, Какое оно, модное слово: к вопросу о параметрах языковой моды, Русский язык за рубежом 2, s. 45-63.

Немзер А., 2006, Хочешь быть животным - будь им. О романе Виктора Пелевина «Ампир В», Время новостей, 230, [online], http:/www.vremya. $\mathrm{ru} / 2006 / 230 / 10 / 167719 . \mathrm{html}$, [23.10.2009].

Нечаева И. В., 2008, Актуальные проблемы письменной адаптации иноязычных заимствований, Автореф. дис. ... канд. филол. наук, Москва.

РозентАЛЬ Д. Э. и ДР., 1999, Справочник по правописанию, произночению, литературному редактированию, Москва: ЧеРо.

Русская латиница, w: Википедия. Свободная энциклопедия, [online], http:// ru.wikipedia.org/wiki/Русская_латиница\#cite_note-1, [8.10.2010].

РозЕнТАЛЬ Д. Э. и ДР., 1999, Справочник по правописанию, произношению, литературному редактированию, Москва: ЧеРо.

СкЛяревСКАЯ Г. Н., 2006, Толковый словарь русского языка начала ХХІ века, Москва: Эксмо.

ФилинковА Е. О., 2001, Варваризмы в периодической печати: динамика и особенности использования (на материале журнала «Наука и жизнь»), Лингвистический ежегодник Сибири 3, Красноярск, s. 166-172.

Юхмина Е. С., 2009, Адаптация иноязычных компьютерных терминовк лексической системе русского языка, Дисс. ... канд. филол. наук, Челябинск, s. 85-89. 


\section{Графическое освоение заимствований из английского языка в русском языке начала XXI века и языковая мода \\ (резюме)}

Большое количество иноязычных слов заимствуется русским языком из европейских языков, использующих иную, чем русский язык, графическую систему. В связи с этим подчас возникает проблема их графической адаптации. Слово может входить в язык, а точнее, в его письменную форму, и функционировать первоначально не в транслитерации, а в оригинальной записи. Поэтому в русских текстах все чаще появляются слова, записанные латинской графикой. Отношение ученых к сложившемуся в постсоветский период положению вещей в современной орфографии разное, но не замечать этого факта нельзя. В статье это явление рассматривается как пример «модного объекта» (по терминологии А. Б. Гофмана), и феномен смешивания двух графических систем в русском тексте подвергается анализу с точки зрения этой концепции. Автор обращает особое внимание на вкрапления, записанные латиницей в названиях литературных произведений и псевдонимах, сравнивает ситуацию, сложившуюся в постсоветской орфографии, с ситуацией, которая имела место в русском языке в XIX веке. 